УДК 94:356.15.](477)«2014/2018»

ПИТЛЬОВАНА Л. Ю.

https://orcid.org/0000-0002-5700-9992

ТРОЯН С. С.

https://orcid.org/0000-0002-3053-6530

https://doi.org/10.33577/2313-5603.34.2020.239-244

\title{
ОСОБЛИВОСТІ ДОСЛІДЖЕННЯ ВОЛОНТЕРСЬКОГО РУХУ В УКРАЇНІ НА СУЧАСНОМУ ЕТАПІ
}

Про гідність. Волонтерський рух в Україні 2013 - 2017 років. За редакцією Олени Аркуші та Миколи Литвина; упорядники Галина Боднар, Олена Лукачук, Леся Хлипавка; Національна академія наук України, Інститут українознавства імені Івана Крип’якевича, 2018. 816 с.

Книга про волонтерський рух в Україні є збірником статей багатьох авторів об'єднаних однією ідеєю - проаналізувати унікальне явище у вітчизняній історії - волонтерський рух на допомогу Збройним Силам України під час російської агресії. «3 перших пострілів в Україні в центрі як суспільної уваги, так і думок опинилась армія, - пише у вступі Олена Аркуша, - яку останніми десятиліттями витіснили на узбіччя великих дискусій про великі реформи та їх відсутність. Призвичаєне до миролюбної риторики суспільство мало вкрай невиразні уявлення про те, як потрібно воювати і що насправді відбувається 3 його Збройними силами...Буквально за лічені дні стало відомо, що армія перебуває у критичному стані. Утім, це стосувалося насамперед забезпечення і військового спорядження» (С. 12 - 13).

Патріотично налаштовані громадяни України не могли байдуже споглядати за подіями, які вирували на східних кордонах нашої Держави, та всім, чим могли, допомагали військовим, аби останні зуміли вистояти та боронити терени країни. Волонтери, так як і бійці, ризикували своїм життям задля того, щоб захистити

Питльована Лілія Юріївна, кандидат історичних наук, доцент, доцент кафедри історії, Український католицький університет (м. Львів).

Троян Сергій Станіславович, доктор історичних наук, професор, професор кафедри міжнародних відносин, інформації та регіональних студій Національного авіаційного університету (Київ, Україна); професор Жешувського університету (Республіка Польща).

(С Питльована Л.Ю., Троян С.С., 2020 
українське населення та зберегти незалежність Батьківщини. Найбільш суттєвий внесок для посилення обороноздатності України волонтери зробили саме на початку проведення АТО у Донецькій i Луганській областях, коли постачання держави силовим структурам здійснювалося повільно, бракувало систем захисту, обмундирування та продовольства.

У рецензованій книзі розкривається високий рівень суспільної та політичної значущості дій волонтерів, залучення до волонтерського руху допомоги ЗС України громадян різного віку (від школярів молодших класів до пенсіонерів та загалом людей літнього віку) та соціальної приналежності (митці, спортивні фанати-ультрас, представники шоу-бізнесу, бізнесмени тощо). Високий кредит соціальної довіри суспільства відомим на всю країну представникам волонтерського руху став підгрунтям для появи нового класу українських суспільно-громадських, а згодом і політичних діячів.

У багатьох статтях збірника відзначено, що волонтерство як добровільне об'єднання громадянських зусиль для вирішення конкретних завдань має ціннісно-гуманістичну та соціальну природу, є однією з ознак громадянського суспільства. Поряд iз Церквою та армією населення сприймало діяльність волонтерів 3 найбільшою повагою та довірою, як наслідок, волонтери творили нову еліту громадянського суспільства України.

Варіанти участі українських громадян у вирішенні проблем забезпечення та якісного озброєння армії, як і загалом українські волонтерські ініціативи, відрізнялися великим розмаїттям способів $\mathrm{i}$ методів, і збору коштів, і загалом напрямів допомоги. У 2014 р. найгострішими проблемами Української армії та загалом силовиків у зоні проведення АТО були відсутність одягу та взуття, засобів захисту та спецзасобів, засобів гігієни, ліків, незадовільне харчування. Втім, вже в наприкінці 2014 р. українські волонтери вийшли на вищий рівень допомоги та оснащення армії, почавши проєктувати та виготовляти БПЛА, спецтехніку, розробляли системи, зокрема інноваційну технологічну систему артилерійського ведення вогню АРТА тощо.

Переважна більшість авторів статей у збірнику використовують джерела нового типу - матеріали «усної історії». Вивчення «гарячих» подій, які $є$ популярними й емоційно небезпечними для сприйняття, ставлять дослідників перед дилемою суспільного 
осмислення й дотримання терміну давності в подачі матеріалу, водночас зобов'язують фіксувати спогади очевидців подій для подальшого використання. Це доволі нова техніка для українських фахівців-істориків, оскільки до цього часу всі тематичні блоки опитувань стосувались подій, які оповідачі пережили раніше, осмислили їх, приховали й стерли зі своєї життєвої історії. Натомість у розмові $з$ учасниками подій $є$ місце обдуманим сюжетам і міркуванням, які слугують елементами конструювання самого себе як героя, жертви або ж спостерігача - вже на власний вибір.

«Усна історія» - це досить поширений сьогодні напрям соціально-гуманітарних досліджень, який надзвичайно динамічно розвивається і головним предметом якого є суб'єктивний досвід окремої людини. Його основний метод дослідження - інтерв'ю, i в цьому він близький за своєю специфікою до інших наук: соціології, психології, етнографії, етнології, культурної антропології. Хоча складовою поняття є слово «історія», все ж «усна історія» - це не нова галузь історичної науки, а нова методика, спосіб залучення до аналізу нової категорії джерел, поряд із писемними джерелами та матеріальними об'єктами. На сьогодні консенсусу щодо остаточної дефініції «усна історія» не досягнуто, але більшість науковців наголошують на міждисциплінарності цього напряму.

Автори рецензованої книги у рамках проєкту «Діяльність волонтерських організацій як чинник зміцнення обороноздатності України та реінтеграції тимчасово окупованих територій» записали 93 інтерв'ю, які зберігаються в архіві Центру усної історії та біографістики при кафедрі новітньої історії України імені Михайла Грушевського Львівського національного університету імені Івана Франка та в архіві усних історій Інституту українознавства імені Івана Крип'якевича НАН України. Усього у книзі використано близько 200 інтерв'ю волонтерів (С. 22).

Варто було би упорядникам рецензованої збірки залучити i матеріали архіву усної історії Національної академії сухопутних військ імені гетьмана Петра Сагайдачного (НАСВ). У вищому військовому навчальному закладі проводилися опитування курсантів - учасників АТО, науковці Наукового центру Сухопутних військ НАСВ були задіяні у виконанні оперативного завдання 3 проведення усноісторичного дослідження про оборонців 
Луганського аеропорту - військовиків 80-ї окремої десантноштурмової бригади ЗС України, яка розташована у Львові. Це би дало змогу висвітити важливий аспект проблеми, який, на жаль, оминається у книзі - волонтерський рух у рецепції учасників АТО.

Вважаємо, що дослідження у сфері «усної історії» серед учасників АТО ООС повинні тривати й надалі. Такі дослідження сприяють накопиченню, опрацюванню та введенню у науковий обіг історичних джерел; розробці тематичних курсів та навчальних програм для студентів вищих військових навчальних закладів. Слід і надалі розширяти та впорядкувати базу інтерв'юерів учасників сучасної російсько-української війни.

Рецензована книга структурована за такими змістовими лініями: суспільний клімат в Україні напередодні та на початку воєнного конфлікту, де акцент зосереджено на тому, як українське суспільство приймало та усвідомлювало війну, як почало поіншому дивитися на своє військо; історичні аспекти волонтерства (огляд міжнародного досвіду; смисли та контексти терміна «волонтерство»; волонтерські практики в Україні у війнах ХХ століття; волонтери під час Революції Гідності); волонтерство як форма громадського руху (волонтерський рух як предмет аналізу політичних і соціальних наук; його правова база, волонтерство в освітніх стратегіях (йдеться про зміщення емоційних установок до вміння створювати аналітичні моделі); комунікативні практики волонтерів; організовані форми волонтерського руху в умовах бойових дій в Україні (волонтерські організації та ініціативи; життєві історії волонтерів); образи волонтерів у сучасному публічному просторі; комеморація волонтерського руху в Україні; окремі життєві історії волонтерів.

Цікавими і новими аспектами вивчення історії волонтерського руху є статті Мар'яни Байдак «Волонтерські доброчинні практики в Україні у війнах першої половини ХХ століття» (С. 123 - 135), Софії Предко «Зародження інституту військових капеланів» (С. 136 - 144), Олени Лукачук «Мова волонтерів»: звернення за допомогою і способи комунікації» (С. 224 - 235), Мар'яна Мудрого «Формування громадянина України засобами історичної освіти» (С. 252 - 262), Юлії Шелеп «Допомога населенню, що постраждало від бойових дій» (С. $490-502)$ та ін.

У рецензованій книзі частина матеріалу присвячена маловивченій проблемі - військовому капеланству. У 2014 - 2018 роках священнослужителі опинилися поруч із військовиками в районах 
реальних бойових дій та під час виконання ними бойових завдань, відтак актуалізувалося питання щодо інституалізації капеланства, справедливого соціального захисту їх під час діяльності.

У статтях О. Лукачук, М. Литвина, О. Томчука «Зародження капеланської служби у Львові», «Душпастирська опіка у волонтерському русі: окремі приклади» (С. 284 - 301) згадується волонтерська діяльність настоятеля храму архистратига Михаїла, розташованого на території Національної академії сухопутних військ, а пізніше настоятеля гарнізонного храму святих апостолів Петра та Павла у Львові (нині єпископа УГКЦ) о. Степана (Суса). Курсанти та професорсько-викладацький склад Національної академії сухопутних військ у Львові активно були задіяні у волонтерському русі. Окремі офіцери після служби в Академії брали участь у відновленні військової техніки на Львівському бронетанковому заводі.

Завершується книга «Про гідність...» нарисами життєвих історій деяких волонтерів (розділ 6, С. 533 - 686) та біографічним словником респондентів видання (С. 687 - 780). Тут відкритим залишається питання: за яким принципом відібрані респонденти, та й сама доцільність розміщення у рецензованому виданні словника, адже відоме негативне ставлення переважної більшості рядових волонтерів до піару їхньої діяльності.

Бажано було подати наприкінці книги список літератури, що сприяло би використанню історії волонтерського руху у навчальному процесі. Сама книга «Про гідність...»є бібліографічною рідкістю. Радимо упорядникам хоча би розмістити ії на сайті електронних видань установи, під грифом якої здійснений випуск, Інституту українознавства НАН України імені Івана Крип'якевича.

Події, які переживає народ України упродовж сучасної російсько-української війни, ще раз засвідчили, що проголошена у 1991 р. державна незалежність потребує постійного захисту, глибокого розуміння та оцінки того, що відбувається навколо нас. Саме тому на лекціях та семінарських заняттях курсантів та студентів присвячених сьогоденню, особлива увага повинна приділятися ролі учасників бойових дій на сході України та волонтерам. Необхідно акцентувати увагу на тому, що патріотизм в нинішній час проявляється не лише в безпосередній борні на Сході із зовнішнім ворогом, не тільки в надзвичайних ситуаціях, але $\epsilon$ звичайним станом повсякденного життя людини. 
Становлення та розвиток волонтерського руху допомоги 3С України під час проведення АТО є унікальним явищем, аналога якому немає у світовій історії. Без сумніву, саме «народна підтримка» врятувала армію від повного розвалу у 2014 р., а Україну - від втрати державності. Вітчизняне волонтерство повинне стати об'єктом посиленої наукової уваги представників воєнно-історичної науки.

Як і обеззброєна в 2014 році Українська армія, так сьогодні і знекровлена українська медицина не справляється в боротьбі 3 «COVID-19» без підтримки волонтерів i громадянського суспільства. Волонтери і сьогодні взялися за забезпечення медиків найнеобхіднішим - засобами індивідуального захисту, медикаментами, обладнанням і навіть гарячим харчуванням. За підтримки волонтерського руху Україна досягне Перемоги у війні з агресором та подолає пандемію. 